ORIGINAL RESEARCH ARTICLE

\title{
Supporting law students' skills development online - a strategy to improve skills and reduce student stress?
}

\author{
Anne Hewitt and Matthew Stubbs*† \\ Adelaide Law School, The University of Adelaide, Adelaide, Australia \\ (Received 23 November 2015; final version received 28 February 2017)
}

\begin{abstract}
Law students internationally suffer from a high level of psychological distress compared with the general and student populations, and anecdotal evidence suggests that students developing skills without adequate support experience significant stress and anxiety. This article considers an initiative at one Australian law school to develop a degree-wide structured online skills development programme as a means to both improve student skills acquisition and reduce student stress. The project implements, through the use of learning technology, the principles proposed by McKinney for making small changes to law school teaching, informed by self-efficacy theory, which can have powerful results.
\end{abstract}

Keywords: legal skills; online learning; student stress; wellbeing; skills; blended learning

\section{Introduction}

Law schools cater to a variety of stakeholders, some of which may have conflicting interests. In 2003, the Johnstone Report identified 'competing demands ... from the university, from students, from employers and law societies, from admission boards, not all of whom share the same vision for legal education' (Johnstone and Vignaendra 2003, p. 468). Law students rightly demand a high-quality education with good job prospects. Admitting authorities and the legal profession require legal graduates to have a variety of substantive knowledge and skills (Handsley, Davis, and Israel 2005, pp. 112-113; Kift, Israel, and Field 2010). The community requires that graduates be ethical and business competent; universities require that students demonstrate certain 'graduate attributes'. Perhaps this myriad of pressures contributes to the fact that law students Australia-wide suffer from a high level of psychological distress compared with the general and student populations (Tani and Vines 2009).

This article considers a curriculum-wide project at one Australian law school that attempted to balance some of the stakeholder interests in producing skilled law graduates with the school's pastoral obligations towards students through a supported skills development framework. We examined the ability of learning technology to enable us to fulfil our obligation to provide an environment that will maximise learning while also providing the support necessary to minimise student distress. We then created a series of online skills development modules which were deployed throughout

\footnotetext{
†The authors wish to thank Vanessa White for research assistance and Shane Rogers for outstanding assistance with the survey and statistics. The project which informs this article was supported by a 2013 University of Adelaide e-Learning grant.
}

*Corresponding author. Email: matthew.stubbs@adelaide.edu.au. 
the law curriculum, and evaluated them to determine both their efficacy in assisting students to acquire skills, and also their contribution to establishing a supportive learning environment in which student stress was minimised.

In Part 1, this article will more fully explain the requirements for law schools to actively engage with developing students' skills and the efficacy of online skills development pedagogies. In Part 2, the issue of law students' mental health will be briefly explored. Part 3 will consider incidental issues associated with online and blended learning environments for students. Part 4 will introduce the project and Part 5 will summarise the evaluation methodology and results.

\section{Law schools, skills development and the efficiency of online delivery}

It is now accepted that teaching some practical skills to students is necessary in order to equip them for professional life, in whatever field that may be (Australian Law Reform Commission 1999, p. 139, 151; Edwards 1992; Lord Chancellor's Advisory Committee on Legal Education and Conduct 1996, p. 14; Sullivan et al. 2007, p. 13). Expecting students to acquire skills automatically is an ineffective strategy (Woods et al. 2000), and it can lead to disengagement (Deci and Ryan 1985). For many students, it is also likely to negatively affect their perception of their own competence and control, which can contribute to emotional stress and have negative effects on self-esteem (McKinney 2002).

However, developing practical skills often requires a very different method of teaching than is effective for substantive legal knowledge (Hewitt and Toole 2013). Teaching skills can be time and resource intensive, which is problematic in a resource-poor environment (National Alternative Dispute Resolution Advisory Council 2012, p. 30, 33). Thus, developing cost-efficient and pedagogically effective methods for assisting students to acquire skills is important. In this context, online learning tools may be useful. While such resources are often time or cost-intensive to create, online learning tools can often be used multiple times with limited additional commitment of resources (especially in areas which remain relatively static, as some skills do), which may offer long-term institutional cost savings (Butler 2010; Kendrick 2010, p. 1392).

Online learning is not only potentially efficient; it can also be effective. A metaanalysis of research literature on online learning from 1996 to 2008 concluded that 'students in online learning conditions performed modestly better than those receiving face-to-face instruction' (U.S. Department of Education, Office of Planning, Evaluation, and Policy Development 2010, p. 9). There is also some evidence that online learning environments can be used to facilitate the development of specific legal skills (Hewitt 2015; Martin 2003; Yule, McNamara, and Thomas 2010).

\section{Law students' distress}

The well-being of law students in Australia and elsewhere is a matter of concern. A 2009 Australian study of students from 13 tertiary institutions found that law students suffer disproportionately high levels of psychological distress (Kelk et al. 2009). Similar results have also been found in institution-based studies (Leahy et al. 2010; Tani and Vines 2009). Indeed, studies around the world have demonstrated that law students suffer high levels of psychological distress (Dammeyer and Nunez 1999; 
Helmers et al. 1997). This is also consistent with evidence of high levels of psychological distress and risk of depression in the Australian legal profession (Kelk et al. 2009). These results remain disturbing, even though they are now well known.

A variety of reasons have been posited for the high rates of psychological distress suffered by law students. In United States law schools, blame has been attributed to factors as varied as the emphasis on achievement within law schools, and student competition for grades (Nordmo and Samara 2009); the vague process of 'learning to think like a lawyer' which includes a focus on linear thinking at the expense of student creativity and personal values (Culp 1994, p. 69; Peterson and Peterson 2009) and legal formalism (Peterson and Peterson 2009; Stefancic and Delgado 2005 , p. 35). The workload associated with the study of law, limited staff-student interaction and inadequate development of students' interpersonal skills have also been identified as causative factors (Benjamin et al. 1986).

While the Australian context differs from the United States (where law is a purely postgraduate discipline), many of these possible causes ring true here. In Australia, suggested factors resulting in poor mental health amongst law students include heavy workloads, the highly competitive nature of law and law students, inadequate feedback and feelings of a lack of social connectedness, competence and autonomy (Huggins 2012). All these potential causes support the suggestion that law school is a 'breeding ground for depression, anxiety, and other stress related illness' (McKinney 2002, p. 229). However, identifying solutions to the problem is more difficult. Against that background, this project is predicated on the basis that the legal academy has a responsibility to create positive learning experiences for our students, and that a project evaluating the potential for harnessing learning technology to help address this serious issue is both timely and important.

In this context, we have been influenced by Watson and Field (2011, p. 396), who argue for the adoption of a 'range of innovative curricular and co-curricular strategies to support the use of legal education as a tool for the promotion of resilience and wellbeing' and promote student engagement. In developing our project, we have also adopted the principles proposed by McKinney (2002), for making small changes to law school teaching informed by self-efficacy theory, which we hope will have powerful results. Our online learning modules addressing legal skills acquisition respond to this literature on law student distress, as explained in Part 4.

\section{Online learning environments: opportunities and risks}

In addition to their potential efficiency, online learning environments can be pedagogically effective to facilitate substantive student learning. However, there are a number of issues associated with the use of technology in learning that should be considered when students' well-being is also a concern. For example, the benefits of online learning resources such as flexibility and 'just-in-time' access must be weighed against issues of equity and accessibility. This part identifies the opportunities and risks of online learning environments which will be analysed in the evaluation of our online learning modules in Part 5.

\section{Flexibility}

Online teaching and learning offer the potential for levels of flexibility and accessibility that cannot be matched by traditional face-to-face learning. It has been observed that 


\section{A. Hewitt and M. Stubbs}

'students like to use e-learning if it ... allows them to learn any time anywhere in their own way' (Selim 2007, p. 399). Online teaching allows students a greater level of control: for example, compared with the standard face-to-face lecture, online teaching allows students to start, stop, go back or advance, as they wish (Ireland 2008, p. 154) rather than being progressed through the course at the same pace, regardless of their understanding (Glance, Forsey and Riley 2003). Thus, online teaching assists both high- and low-performing students by allowing them to work at their own pace and helping to alleviate the risk of students either becoming bored or left behind in a classroom geared towards 'average' students.

For example, a 2008 Australian study of online teaching in an intellectual property law course found that podcasts were particularly popular with students, and noted that 'inclusion of podcasts ... clearly introduced a whole new level of flexibility' (Ireland 2008, p. 154).

\section{Student-driven learning}

Online learning can also provide students with a safe, private learning environment in which they can experiment with new skills (Martin 2003, p. 92), and work through the material at their own pace (McNamara 2000, p. 167). Because online learning is flexible, it provides an opportunity for students to engage in 'mastery learning' (Guskey 1997) by breaking material into small stages, with assessment, before moving from one stage to the next, to ensure that students master each concept before progressing.

Traditionally, mastery learning is a teacher-paced and classroom-based system, with the primary source of instruction being the teacher. However, another form of mastery learning developed by Keller (1968), called Personal System of Instruction, is a student-paced system, where the primary source of instruction is learning materials, so students can take course units at any time that suits them (Grant and Spencer 2003; Keller 1968, p. 79). Online modules can usefully contribute to this pedagogy.

\section{On-demand revision of previously learned concepts}

Online content has the obvious advantage that it is available for on-demand revision. Some research suggests that repeated studying after learning produces no significant effect on ability to recall material, although repeated testing results in a large positive effect (Karpick and Roedinger 2008). However, student feedback to the authors suggests that on-demand revision is of significant benefit to learning outcomes, and an Australian study confirms high usage rates of content recorded for later revision (Mascher and Skead 2011, p. 421). There is also some evidence that on-demand revision is beneficial to learning outcomes (Ireland 2008, p. 154; Mascher and Skead 2011, pp. 429-430; McKinney, Dyck and Luber 2009).

\section{Equity}

Equity issues exist in all teaching modes, although the online environment may tend to negate some issues, while amplifying or introducing others (Coldwell et al. 2007, p. 10). Four significant equity issues in online teaching will be considered below. 


\section{Digital literacy and access}

Digital literacy is critical to a student's ability to learn effectively in a digital environment (Cagiltay 2006; Hill and Hannafin 2001; Selim 2007; Schrum 2002). The importance of examining the interaction of digital literacy with online education increases now that the popular notion of tertiary students as universally comprising 'digital natives' (Howe and Strausse 2000; Tapscott 1998) has been debunked (Buckingham 2007; Hartman, Moskal, and Dziuban 2005), not only for mature-age students (Oliver and Goerke 2007), but also for students in general (Lorenzo, Oblinger, and Dziuban 2007).

\section{Disability}

Online teaching may have complex impacts on students with a disability. It may reduce barriers faced by physically disabled students, including transport difficulties and mobility restrictions, which can make attending classroom-based teaching difficult. For students with a learning disability, e-learning may allow them to work at their own pace, to adapt materials to suit their needs, and may facilitate communication with peers and teachers (Fichten et al. 2009, p. 250). Online learning may also allow students with a disability to choose whether to reveal their disability at their discretion, while promoting equity and reducing discrimination (Fichten et al. 2009, p. 242; McFarland and Fuller 2001). However, online learning may also exclude students with a disability if it is not thoughtfully designed to be mindful of their accessibility needs (Fichten et al. 2000, 2001; McFarland and Fuller 2001). For example, use of online learning can pose problems for students with learning, visual and neuromuscular disabilities if it impairs their ability to use adaptive software capable of screen magnification, screen reading and dictation (Burgstahler, Corrigan, and McCarter 2004, p. 234; Seale and Cooper 2010, p. 1108).

\section{Gender}

Evidence collected a decade ago suggested that women were less enthusiastic about using information and communication technologies than men (Katz 2006). According to Kirkup (2002, p. 13), the online environment is 'a gendered world operating in similar ways to the material world'. Studies reported that women displayed higher levels of computer anxiety and lower levels of self-efficacy towards computers and the Internet than men (Comber et al. 1997; Durndell and Hagg 2002; Okebukola and Woda 1993; Whitely 1997). However, more recent research suggests that the online learning environment is no longer intimidating to female students. For example, a 2007 Australian study found no significant differences between female and male students with respect to being able to use an online learning environment confidently and effectively (Coldwell et al. 2007, p. 15). Indeed, greater value was placed by female students on using the online environment for communicating and collaborating with students from diverse backgrounds, and it has been suggested that the anonymity afforded by online environments could be empowering for women (Coldwell et al. 2007, pp. 19-20).

\section{International students}

There is surprisingly little consideration of international students' perceptions of online learning. Existing studies have reached conflicting conclusions that cultural 


\section{A. Hewitt and M. Stubbs}

difference can have a negative effect on students' participation in online learning (Shattuck 2005) or that cultural differences are mitigated in online education (Walker-Fernandez 1999). Limited language proficiency can clearly affect learning outcomes (Zhang and Kenny 2010). Ireland (2008, p. 154) noted that the on-demand revision facilitated by online learning was particularly beneficial 'for international students and those for whom English is a second language.' However, learners in an online environment may feel isolated and uncertain because of the absence of nonverbal cues and social presence (Muilenburg and Berge 2005), which may be particularly challenging for those international students raised in a cultural environment in which social context is emphasised (Ky and Lohr 2003).

\section{The project}

\section{Introduction and aims}

This project was designed to address the significant issues with law student distress identified in Part 2, as well as to respond to areas for improvement within legal skills teaching identified both as a result of a curriculum mapping exercise and also on the basis of a 2012 survey of the whole Bachelor of Laws (LLB) student cohort (and associated focus groups) which identified flexibility, accessibility and consistency of skills teaching as areas for improvement. ${ }^{1}$ The aims of our project were, therefore, to reduce student stress and maximise students' satisfaction with their learning experience by providing scaffolded support in legal skills development across the LLB curriculum. The project design was also informed by self-efficacy theory.

\section{Self-efficacy theory}

The term 'self-efficacy' was developed to explain how individuals' perceptions of their own competence and control develop, and affect their ability to cope with actual challenges (Bandura 1977). The theory has been used by McKinney (2002) to inform the development of curriculum to minimise depression and anxiety amongst law students, and maximise their satisfaction and academic achievement. In essence, self-efficacy theory indicates that promoting a personal belief that you can control an outcome and achieve a desired result is likely to also increase the effort expended to achieve the result and, as a consequence, the result realised, and thus to improve self-esteem in addition to improving the achievement of the learning outcome (Maddux 1995). There is evidence linking a lack of self-efficacy to depression (Maddux 1995; Maddux and Meier, 1995) and anxiety (Lloyd Williams 1995). In a law school, the theory suggests that increasing the self-efficacy of students will not only increase the chances they will succeed, but will also reduce anxiety and promote wellness through improving self-esteem (McKinney 2002, pp. 245-255).

A person's degree of self-efficacy is affected by four factors (McKinney 2002, p. 237):

(1) Personal and imagined experience;

(2) Vicarious experience;

(3) Feedback and

(4) Physiological and or emotional reactions to an event. 
Our project focussed on the aspects of personal experience and feedback. We sought to develop tools that would allow students to master particular skills through activity, creating an increased belief in their personal capacity. This was supplemented by the provision, throughout the modules, of feedback developed to be positive, and to focus on those parts of the module already completed, which has been demonstrated to increase self-efficacy (Bandura 1997, p. 103, 106).

The modules were also designed to be implemented with a focus on courses early in the degree, at the point when students were mastering the particular skills each module addressed. This was both a practical pedagogic tool, and one that would increase the impact of the modules on improving self-efficacy; positive messages about ability are most effective in increasing self-efficacy when provided early on in the development of a new skill (Bandura 1997, p. 102).

\section{Methodology}

This project commenced with a review of the literature to identify best practice in flexible skills development, focussing on online teaching methodologies. This review demonstrated that it was feasible to develop online resources to enhance students' legal skills, and identified some of the equity and access issues which could be managed through planning. For example, it was determined that issues of digital literacy and access could be minimised by the choice of an accessible online tool to deliver the modules developed, which was compatible with the other learning management software used within the university, and was supported by our information technology team. After considerable research, and after waiting for the results of an internal audit of all learning technologies, it was decided to use Articulate Storyline for the project. The anticipated benefits of this particular technology were that it would:

- Be sufficiently intuitive and user friendly as to minimise access issues for all students, regardless of age or level of digital literacy; and

- Facilitate accessibility for all students by allowing for easy creation of pdf versions of the modules which can be printed as a learning tool and accessed by students requiring the use of assisted reading technologies, and permitting the use of both audio and text instruction where desired.

The second stage of the project consisted of consultation with our colleagues to determine which skills should be addressed, and how the support tools developed could best be integrated within the LLB curriculum. This research was the foundation on which we planned the development of 10 online learning modules which would focus on foundational skills, be embedded in compulsory courses, and be concentrated in the early years of the LLB curriculum. It was also decided that the resources should be centrally available to all students, to facilitate their use as revision and 'just-in-time' learning tools.

The skills addressed by each module, and the course in which the module sits, are set out in the table at the top of the following page. ${ }^{2}$

In designing the modules using Articulate Storyline software, we focussed on:

- Adding to the range of learning resources available to students, so as to cater to the diversity of learning styles; 


\begin{tabular}{|c|c|c|}
\hline & Skill & Course and year level \\
\hline 1 & $\begin{array}{l}\text { Preparing for and engaging in seminars for } \\
\text { effective learning }\end{array}$ & $\begin{array}{l}\text { Foundations of Law [Year } 1 \text { (Y1), } \\
\text { Semester 1 (S1)] }\end{array}$ \\
\hline 2 & Locating, using and understanding legislation & Foundations of Law (Y1, S1) \\
\hline 3 & Locating, using and understanding cases & Foundations of Law $(\mathrm{Y} 1, \mathrm{~S} 1)$ \\
\hline 4 & Locating and using secondary sources & Principles of Public Law (Y1, S2) \\
\hline 5 & Citing legal resources correctly & Principles of Public Law (Y1, S2) \\
\hline 6 & Writing a legal essay & International Law $(\mathrm{Y} 1, \mathrm{~S} 2)$ \\
\hline 7 & Advanced case analysis & Equity (Y2, S1) \\
\hline 8 & $\begin{array}{l}\text { Professional legal ethics in corporate law } \\
\text { settings }\end{array}$ & Corporate Law (Y2, S2) \\
\hline 9 & Writing a letter of advice to a client & Evidence and Proof (Y3, S2) \\
\hline 10 & Academic honesty & - \\
\hline
\end{tabular}

- Giving students greater autonomy in their learning, by creating resources which students can access at the time and place of their choosing;

- Supporting students in the development of foundational skills which we have anecdotal evidence are often found challenging;

- Utilising delivery strategies that are engaging, empowering, motivating and active; and

- Increasing self-efficacy by helping students to master new skills, and providing positive feedback at an early stage of the skills acquisition process.

After refining the module design to take into account feedback from conference presentations (Hewitt and Stubbs 2013; Stubbs and Hewitt 2013), consultations with the coordinators of the courses to which the modules related, and feedback from two external expert referees, ${ }^{3}$ the modules were finalised. In February 2014, they were deployed to students via course-specific Blackboard sites as well as a specifically created 'Professional Legal Skills' Blackboard site into which all law students were enrolled. Each of the 10 modules integrated information delivery with a variety of engagement and active learning strategies, including

- Embedded activities;

- Self-evaluation opportunities;

- Provision of positive and constructive feedback; and

- Links between resource content and students' day to day experiences.

Following deployment, investigation of the modules' efficacy was conducted by way of an online survey, and student focus groups. ${ }^{4}$

\section{Evaluation}

\section{Sample}

A total of 277 students studying at the University of Adelaide Law School in Semester 1, 2014 responded to this survey. The vast majority of respondents $(95 \%)$ were LLB students, with postgraduate students amounting to only $5 \%$. The mean age was 23.83 years $(\mathrm{SD}=7.78)$. The gender distribution was $66 \%$ female and $34 \%$ male, which closely matches the distribution of the law student population. Ten per cent of participants were international students, which again is similar to the population 
of law students. Respondents were also relatively evenly distributed across year levels, as Figure 1 depicts.

The number of participants that had completed each module (and a subset that had not completed any modules) is presented in Figure 2. The number of students participating in the academic honesty module reflects the fact that, for many students, this module was compulsory (whereas all other modules were optional).

\section{Efficacy in assisting students to acquire skills}

As demonstrated by Figures 3 and 4, survey respondents largely agreed that the modules were useful and, overall, students had a positive opinion of the ability of the modules to complement traditional learning. As Figure 3 demonstrates, there is a noticeable difference in perception of usefulness from students at different year levels. Although students at all levels found the modules useful, first-year students reported the greatest satisfaction. This likely reflects that students in later years will

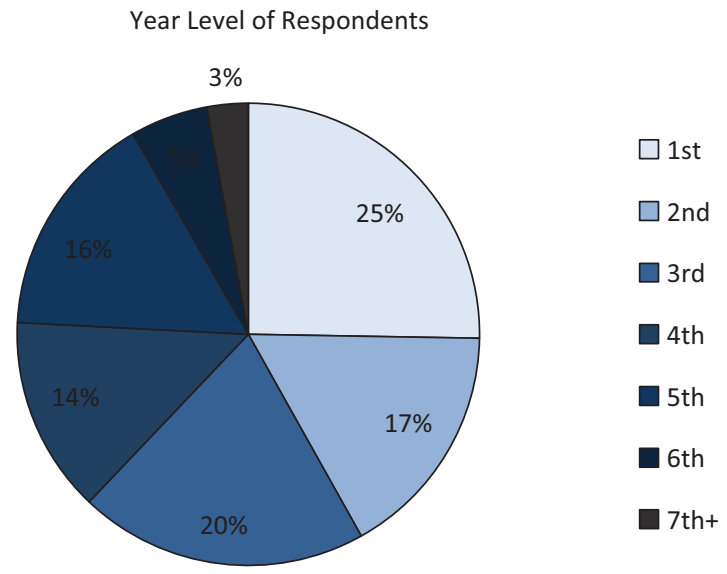

Figure 1. Distribution of sample across different year levels.

Number of participants

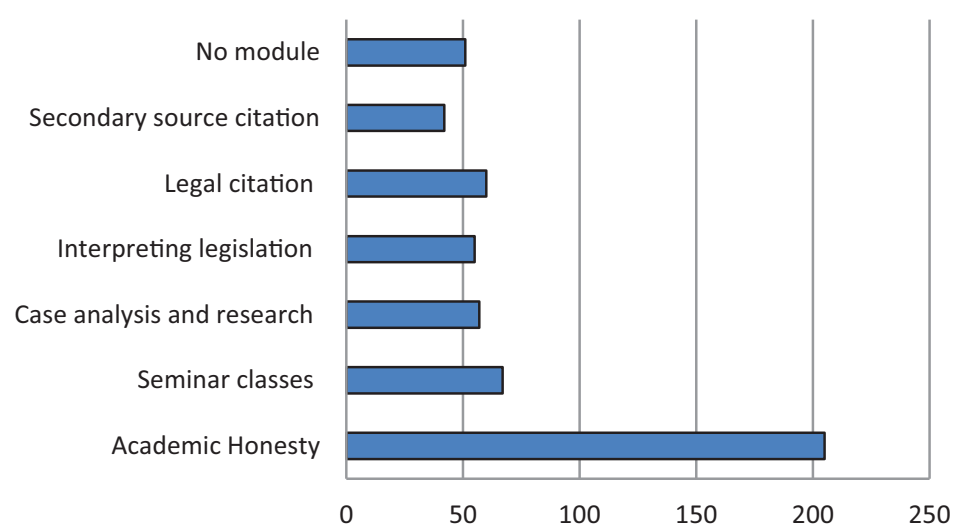

Figure 2. Number of participants completing each of the assessed modules (or no modules). 


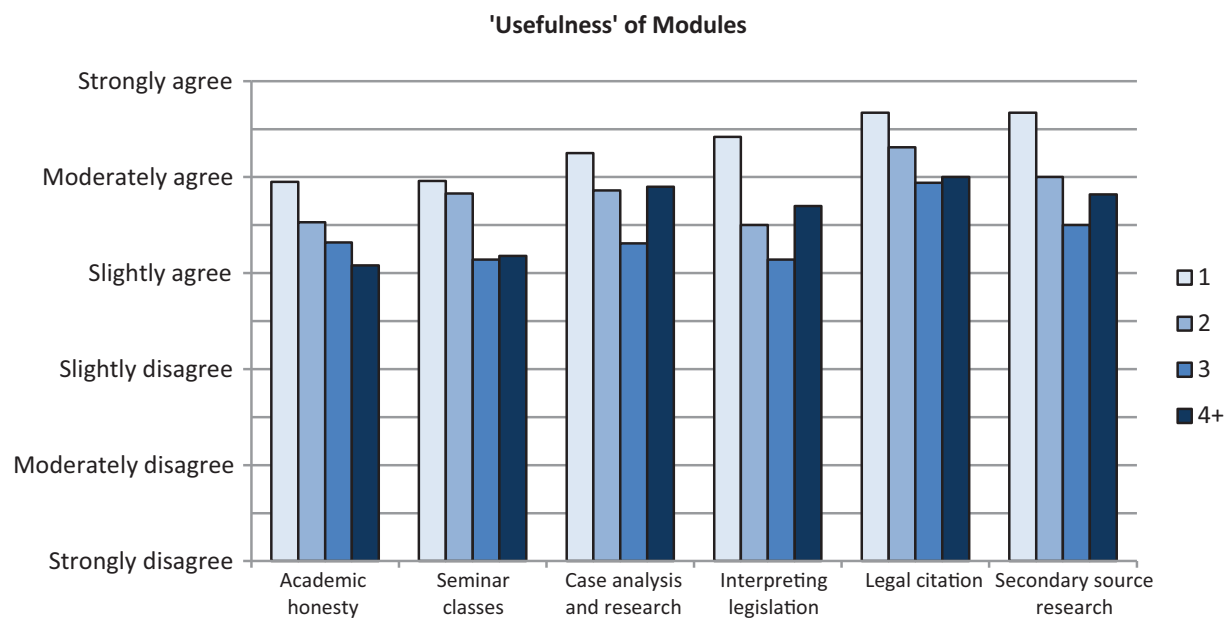

Figure 3. 'Usefulness' of each module across four different year group levels.

have had other opportunities to acquire the skills that these modules aim to teach. This also reflects the project design, as the modules were primarily aimed at fundamental skills acquisition and predominantly embedded in lower-level courses. Nonetheless, later-year students were still positive about the modules. Indeed, one participant in the focus group noted approvingly that 'It took me 3 years to learn the things you could get out of these modules'. Another commented: 'Coming into law I didn't know anything. I wish I had used these modules 4 years ago!' Another student emailed us to say:

I've just transferred from [another Group of 8 University Law School] and I wasn't sure if I needed to do them, but ... they were great, especially the research based modules. I wish I had done something like this back when I started my law degree ... I probably would have saved a lot of time and effort.

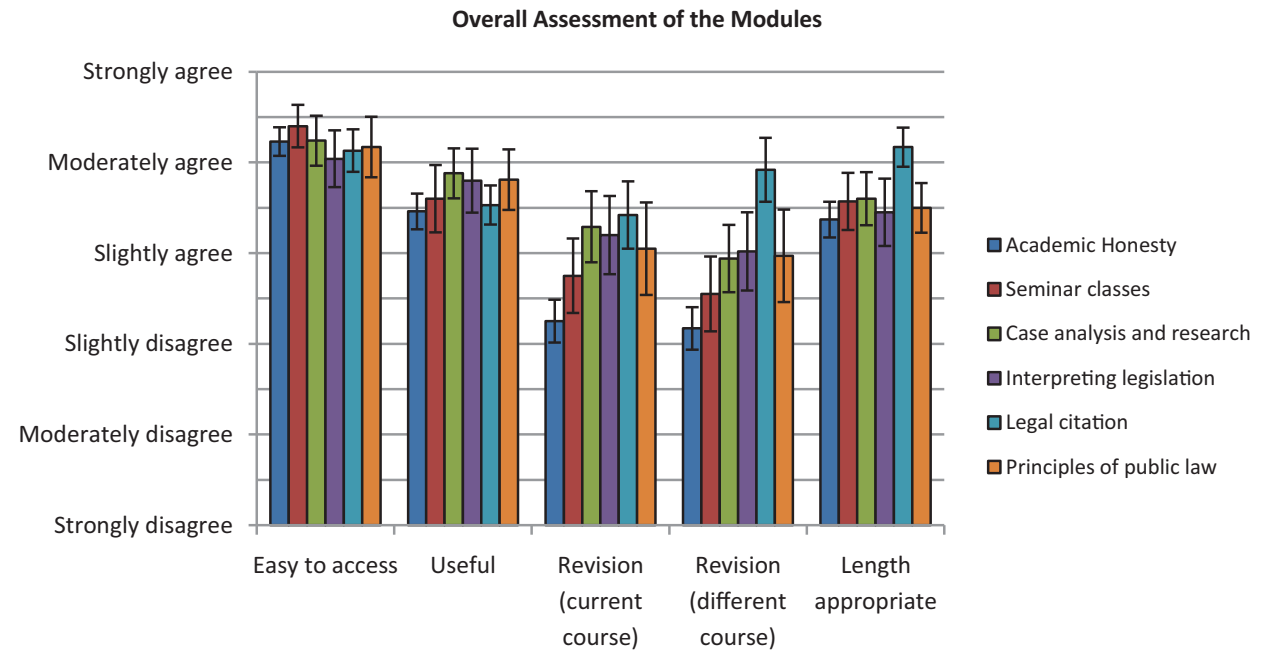

Figure 4. Mean ratings for the different evaluation questions for each module. 
Survey participants were also asked to comment on individual modules. A common source of dissatisfaction was the requirement for all students to complete the academic honesty module. This demonstrates a resistance by students to skills modules being compulsory. However, student text responses indicate that this is a feature of the modules being introduced at a time when many students had already been studying for a number of years. The most common comments on the compulsory academic honesty module were that it was not appropriate for final year students but would be excellent for first year students. One student described the modules as 'relevan[t] and important for first years' but 'unnecessary for final year students'.

The overall assessment of modules by participants for the different questions asked is presented in Figure 4. Participants reported that the modules were easy to access, and useful, with no large difference between modules. Their length was also typically perceived to be appropriate.

On the whole, participants did not respond as positively regarding the likelihood of them revisiting the modules for revision purposes. This is particularly the case for the academic honesty and seminar classes modules. Presumably, once students were aware of the information contained within these modules, they felt they had 'got it', with not much subsequent need for revisiting the information. Nonetheless, as one focus group participant noted, 'having the modules accessible for revision would be beneficial for many students'; another student emailed us to ask 'will the modules remain up on [Blackboard]? I'd like to be able to go back and access them again once I've got a research assignment'. Overall the response regarding likely revision was positive for all except the academic honesty module, albeit that the student response regarding revision was not as strong as elsewhere.

\section{Features of the modules most appreciated by students}

Participants who completed one or more online modules were asked to provide their level of agreement (on a 1-6 Likert scale) with a number of statements regarding the capacity of online modules to complement more traditional forms of teaching. The responses to these statements are presented in Figure 5. Overall, participants appear to have a positive appraisal of the ability of online modules to complement their learning.

Respondents identified as the most favourable features of the online learning modules their ability to clarify expectations and provide flexibility for students to control their own learning timetables. Students were also positive about the modules' capacity to facilitate review of the learning materials on demand (notwithstanding that student intention to use the modules for revision, reported in Figure 4, was not especially strong), and the fact the modules offered a greater variety of materials to support their learning.

Students viewed the modules as complementary to their traditional skills learning, but were not as strongly in agreement as to how much new knowledge and skills was gained as opposed to opportunities to further develop skills already understood to some extent. This might suggest that students felt that online learning was most useful when reinforcing material introduced at least at a basic level via traditional face-toface teaching.

Student responses to qualitative questions identified the use of practical examples as a significant strength of the modules. One student observed '[I] liked how 


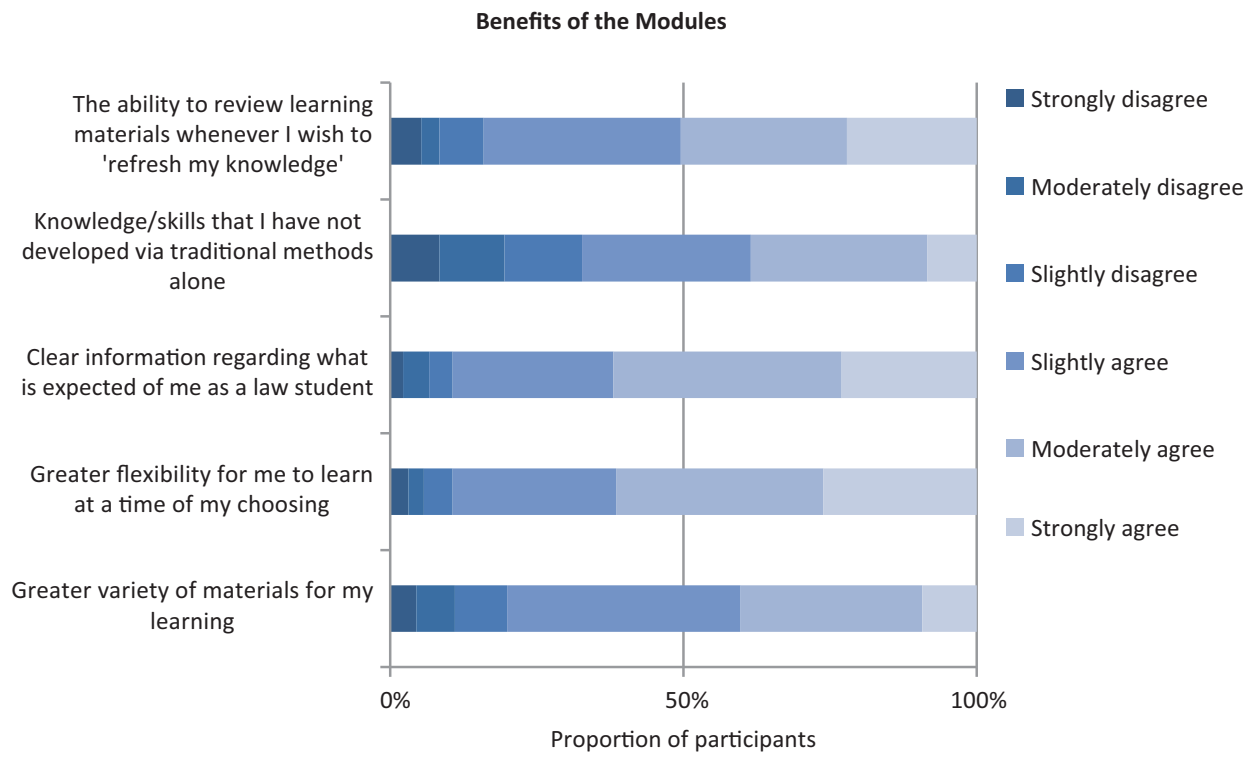

Figure 5. Participant agreement with a number of statements about ways that online modules can complement traditional teaching methods.

it was guided, step by step with examples of each concept', another praised the inclusion of 'lots of examples which helped', and another told us they 'particularly liked reading the real-life situations'. Similarly, a focus group participant commented that ' $[\mathrm{t}]$ he really practical examples were quite helpful'.

Students also commented positively on the extensive provision of formative feedback through practical problems and quiz questions deployed throughout the modules. One student identified as the best feature of the modules that the '[p]lacement of relevant test questions immediately after each section was helpful in clarifying learning'; another said 'I liked the problem scenarios'; another told us 'I particularly liked the test questions'.

That students especially commented on the use of real-life examples and provision of timely formative feedback as part of these online modules reminds us that pedagogy remains an essential foundation on which to build when implementing teaching innovations through technological means.

\section{Student ranking of the benefits of the modules}

Participants were asked to rank some advantages that online teaching modules can provide in order of importance ( 1 being the most important). Their responses appear in Figure 6 below. Overall, law students perceived that obtaining extra opportunities for revision to prepare for assessments was the most important advantage online teaching methods can provide (compared with the comparison options). This was followed by having additional information presented to help them improve upon their skills.

The critical themes to note are the assessment-centric focus by students, and the modules being appreciated as a supplement and extension of material introduced in traditional face-to-face classes, as well as being valued as a means of teaching additional skills not included in the traditional curriculum. 
Ranking of Benefits of Online Teaching Methods

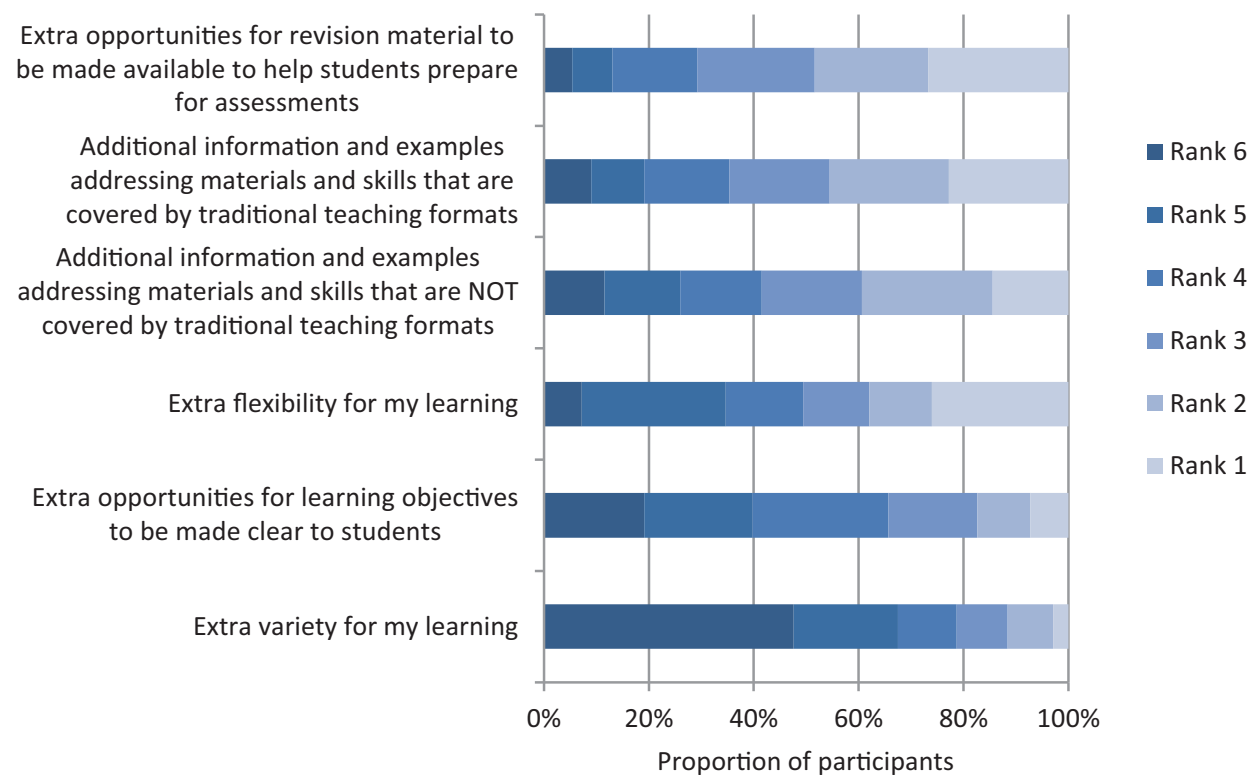

Figure 6. A number of benefits of online teaching methods rank ordered from 1 (most important) to 6 (least important). This question was completed by participants who had experience with one or more of the online modules assessed by this survey.

Interestingly, flexibility was not the most highly ranked attribute of the modules in terms of student perceptions of importance, although students did agree that the modules had been successful at providing increased flexibility in their study. As set out in Figures 5 and 6, respondents generally agreed that not only is increased flexibility important for their learning but also online learning provides that flexibility. This both reflects the importance ascribed to flexible learning and recognises the success of the project in this area. However, although students agreed the modules provided clarity around learning objectives, and introduced variety (one student commented that the modules added 'an appreciated variety to traditional learning methods, feels not like typical studying and more like a quiz or game'), overall these benefits were valued less than the substantive skills-learning outcomes.

\section{Impact of the modules on reducing student stress and anxiety}

A majority of participants agreed, as set out below in Figure 7, that developing legal skills is stressful. One student explained in the focus group how the modules could reduce student stress associated with skills acquisition:

There is nothing worse than sitting on Lexis Nexis and you know you are typing in the wrong search terms - and you know the information is out there - but you are doing the wrong thing and figuring out what to do. Being able to know what you need to know would be invaluable.

Importantly, students also agreed that the online modules provided useful support to assist in the development of skills, and that knowing they could redo modules at any 


\section{Perceptions of Online Learning Methods}

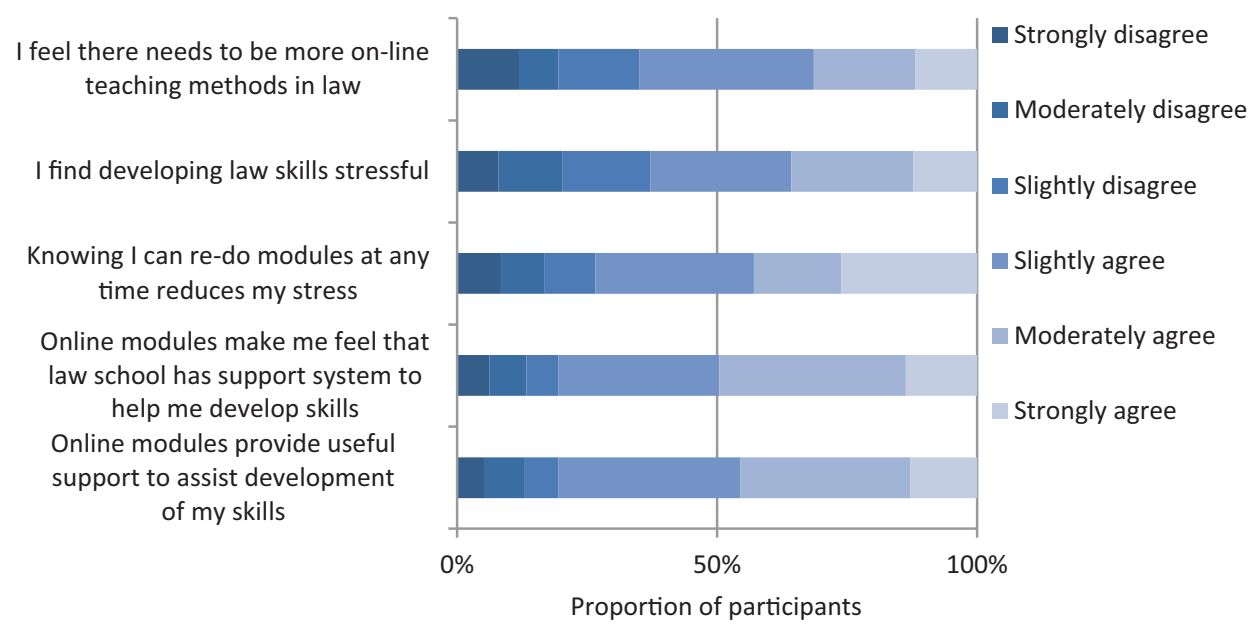

Figure 7. Participant agreement with a number of general statements regarding online learning methods. For the statements 'I find developing law skills stressful' and 'I feel there needs to be more on-line teaching methods in law', there was no significant difference found between participants with or without any experience of the online modules assessed in this survey. The remainder of statements presented in this Figure were only asked of participants that had experience with one or more online modules.

time reduced stress. Furthermore, the majority of participants agreed that the presence of online modules made them feel the law school has a support system to help them develop skills. Similarly, as depicted in Figure 6, students praised the fact that the online modules facilitated the ability to review learning materials whenever they wished and the extra opportunities that such modules provided for revision material to be made available. Not surprisingly after the consistently high positive response evident from the previous questions asked in this survey, the majority of law students felt there needed to be more online teaching methods in law school.

The critical messages from these responses are that (1) the majority of students find skills acquisition a stressful process, (2) these online modules were positively regarded by students as evidence of support by the school and (3) the availability of the modules, and their ability to support review as desired, was perceived by students to reduce their stress. These results confirm the expectation that skills acquisition contributes to law student stress, and the hypothesis underlying this project that online modules can contribute to mitigating the stress that students experience when they are learning new skills.

\section{Evolutionary but not revolutionary benefits}

An examination of how students' experiences with the modules impacted on their perceptions raises a cautionary note regarding the strength of the impact of the modules. For a number of skills pertaining to each of the modules, survey participants were asked whether they felt confident of what was expected of them regarding those skills; 
whether they believed they had the necessary knowledge and skills to perform at a high level; and their perception of the quality of the law school's teaching in the relevant area.

The responses, as set out in Figures 8-13, demonstrate that in most cases students who had completed the relevant module were only slightly more confident or satisfied with the quality of education than those who had not completed the relevant module but who had experience with one or more other online modules, and this second group itself was only slightly more confident or satisfied than the group of students who had not completed any modules. Thus, the impact of participating in an online module on these key outcomes is demonstrable but not revolutionary. However, considering that these modules are only one method whereby students learn the skills in question, and that the modules themselves are a one-off short experience, even a moderate impact can be taken as a success.

Overall, these results support the positive impact of the modules, but caution against overstatement of their beneficial effects. Further, that students were almost as positive if they had taken any module, as opposed to the specific module addressing the skill being interrogated, suggests that part of the benefit of the modules is the knowledge that they exist and the general feeling of comfort and pastoral care it generates. This supports the findings reported in Figure 7 that the modules both reduce stress and give students the feeling that a support system is in place to assist them.

\section{Minimising the downsides of online learning}

The effective use of online learning to establish a supported learning environment is predicated on the minimisation of the potential disadvantages, which include the equity and accessibility issues discussed above. Amongst these, the issue most commonly identified by respondents in their comments was digital literacy and access. While the majority of respondents agreed that the modules were easy to access, appealing and user-friendly, several students, particularly mature-age students, noted difficulties associated with using the technology. Further, several students noted other accessibility issues including difficulties associated with translating words due to the inability to copy the text within the modules, the lack of a text-to-speech tool and the incompatibility of the modules with certain operating systems. Some students also commented that they would be more likely to use the modules on an ongoing basis if they allowed the user to download, print or copy material from them,

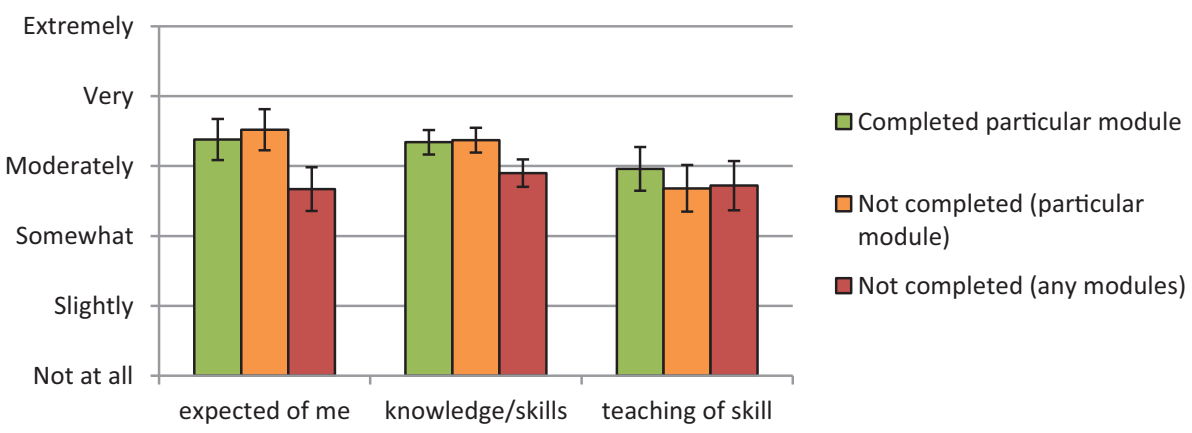

Figure 8. Ratings for skill 'Being an active member in seminar classes'. 


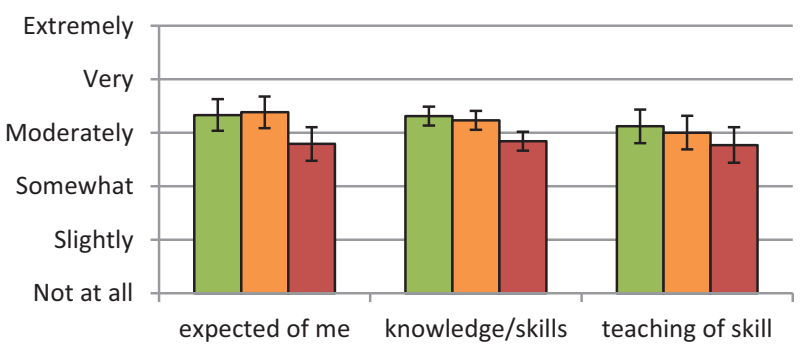

Figure 9. Ratings for skill 'Finding and using cases'.

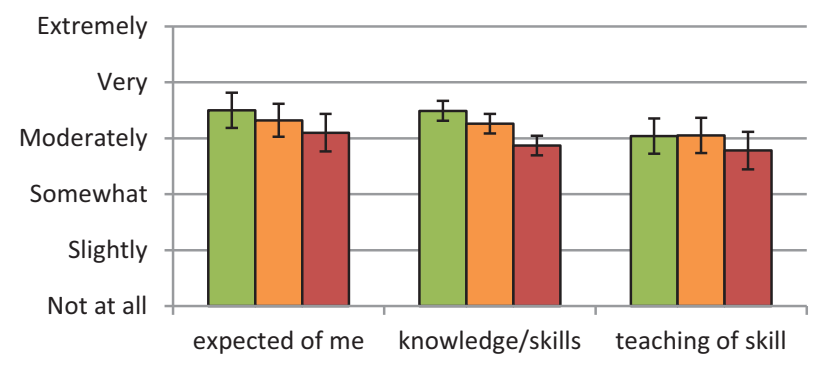

Figure 10. Ratings for skill 'Interpreting legislation'.

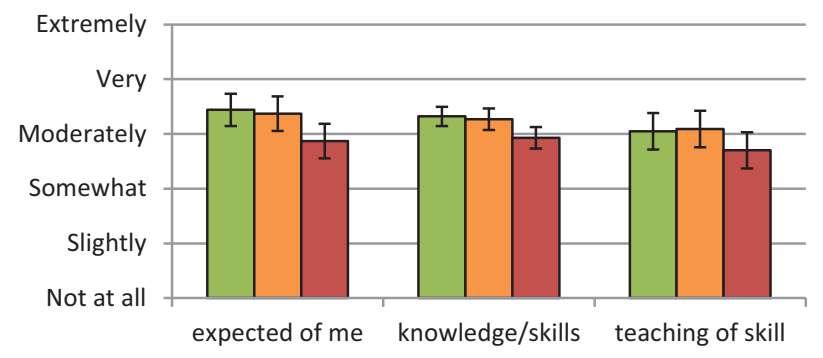

Figure 11. Ratings for skill 'Legal citation'.

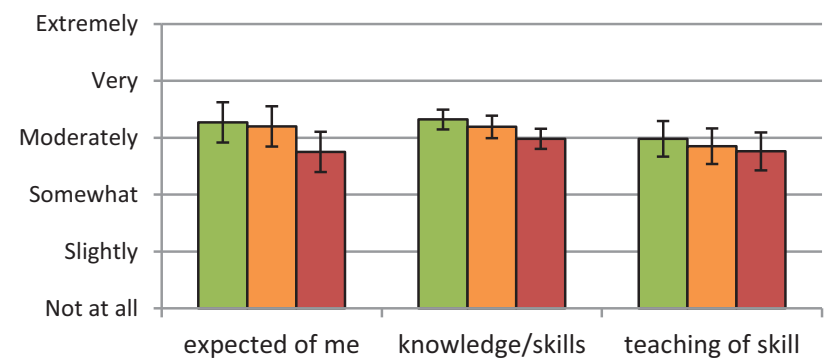

$\square$ Completed particular module

$\square$ Not completed (particular module)

$\square$ Not completed (any modules)

Figure 12. Ratings for skill 'Finding secondary sources'. 


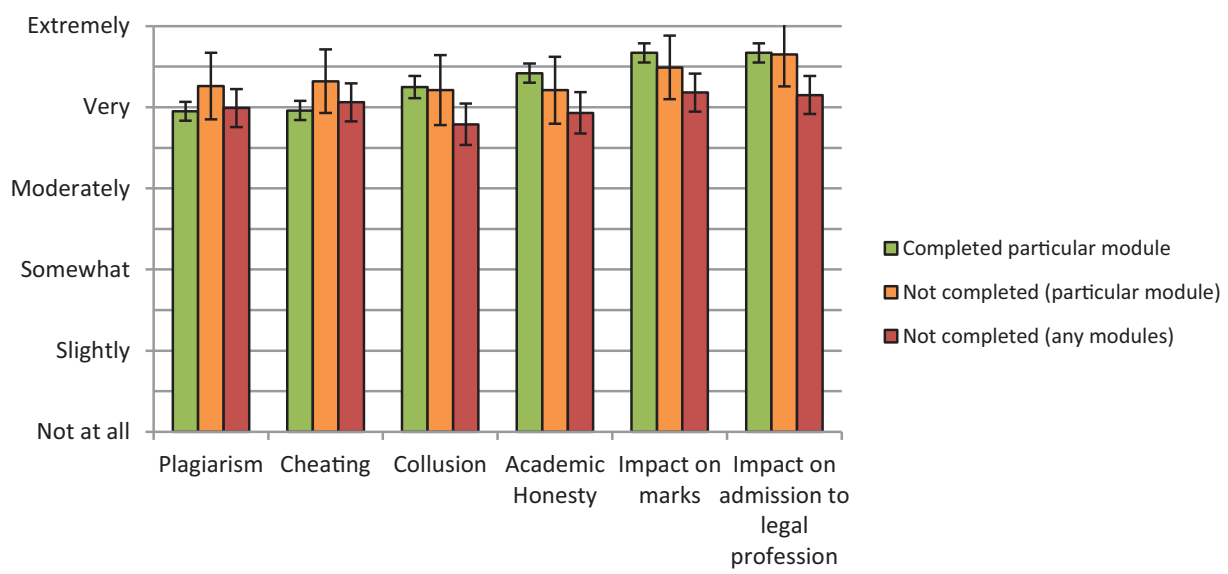

Figure 13. Ratings for confidence in understanding for a number of concepts related to academic honesty.

rather than having to revisit and resubmit the entire module. This may suggest an accessibility issue. In fact students did have the ability to download a pdf file of all instructional slides from each module, but for a small number of students this was evidently not obvious, so greater efforts were made in a later revision of the modules to draw all potentially helpful features to the attention of students.

Further, while a benefit often attributed to online learning is that it allows students a greater level of control over how the information is delivered to them, a number of the respondents did not feel that this was necessarily the case with these online learning modules. Despite the fact that the length of the modules was generally perceived to be appropriate, several respondents were of the view that the modules would be more effective if broken down into smaller component parts. This would more effectively provide the flexibility for students to move through topics in a non-linear way, which some students felt was inhibited by the need to complete the entire module in a step-by-step fashion, including when revisiting the module.

\section{Cohort analyses}

The literature examined earlier raised the possibility that student experiences might differ on the bases of gender, age, domestic or international student status, disability and stage of advancement through the degree. Examination of the data reveals that only two of these factors are accompanied by a statistically significant difference in survey responses.

\section{Disability}

The survey did not ask students to self-report disability, so no quantitative indication can be given of the impact of disability on the student experience of the modules. There were also no free text responses addressing disability as an issue. Some free text comments were positive about accessibility more generally - students noted appreciatively that the modules were 'easy to follow', 'simple to use', and '[s] 
traight forward with an appealing design'. Thus, accessibility of the online modules generally was regarded positively, and we were not made aware of any access issues for students with a disability.

\section{Gender}

Our data indicates that gender was not a factor affecting the student experience of our online modules. Responses to questions regarding the benefits of the modules did not vary significantly across genders, as Figure 14 (below) shows.

The magnitude of these results is fairly comparable, and all show a more favourable response from female students. However, none of these differences in mean was statistically significant in a series of independent samples $t$-tests. Thus, our findings support that branch of the literature (including Coldwell et al. 2007) that suggests there is not a gender difference in engagement with online learning.

\section{Age and progression through the degree}

Some differences in student responses were observed according to both age and progression through the degree. The only statistically significant difference according to age was not to do with the modules at all, but concerned the question 'I find developing skills relevant to the study of law to be a stressful aspect of my learning'. Students under 21 years of age agreed with that statement $(4.11, n=125)$ compared with students aged 21 years or over who were ambivalent $(3.5, n=101)$, the difference being statistically significant [independent samples $t$-tests, $t(224)=3.13, p<0.05$ ] The lack of different experience of the modules according to age supports that part of the literature analysed above which suggests that age is not very relevant in understanding students' abilities to interact with online learning (including Lorenzo, Oblinger, and Dziuban 2007), although a small number of qualitative comments by mature-age students suggest that some members of that cohort experience challenges.

Figure 3 revealed that students were considerably more positive about the online learning modules if they were earlier in their degree, whereas more advanced students were less positive (presumably because they had already developed the skills being taught). This difference according to advancement in the degree was statistically significant in four categories, as Figure 15 shows:

\begin{tabular}{|c|c|c|c|c|c|}
\hline \multicolumn{6}{|c|}{$\begin{array}{l}\text { I feel that the on-line modules I completed have complemented the more traditional learning methods } \\
\text { (i.e. lectures and seminar classes) by providing: }\end{array}$} \\
\hline $\begin{array}{l}\text { Mean } \\
\text { Response for } \\
\text { Gender: }\end{array}$ & $\begin{array}{l}\text { Greater variety } \\
\text { of materials for } \\
\text { my learning }\end{array}$ & $\begin{array}{l}\text { Greater } \\
\text { flexibility for } \\
\text { me to learn at a } \\
\text { time of my } \\
\text { choosing }\end{array}$ & $\begin{array}{l}\text { Clear } \\
\text { information } \\
\text { regarding what } \\
\text { is expected of } \\
\text { me as a law } \\
\text { student }\end{array}$ & $\begin{array}{l}\text { Knowledge/skills } \\
\text { that I have not } \\
\text { developed via } \\
\text { traditional } \\
\text { methods alone }\end{array}$ & $\begin{array}{l}\text { The ability to } \\
\text { review learning } \\
\text { materials } \\
\text { whenever I } \\
\text { wish to 'refresh' } \\
\text { my knowledge }\end{array}$ \\
\hline Female $(n=152)$ & 4.20 & 4.72 & 4.74 & 3.92 & 4.49 \\
\hline Male $(n=74)$ & 4.01 & 4.59 & 4.49 & 3.74 & 4.30 \\
\hline
\end{tabular}

Figure 14. Gender differences in mean student responses 


\begin{tabular}{|l|l|l|l|l|}
\hline $\begin{array}{l}\text { Mean Response for } \\
\text { Students According } \\
\text { to Degree } \\
\text { Progression: }\end{array}$ & $\begin{array}{l}\text { The on-line } \\
\text { modules I } \\
\text { completed } \\
\text { provided useful } \\
\text { support in assisting } \\
\text { me to develop my } \\
\text { skills }\end{array}$ & $\begin{array}{l}\text { The fact that these } \\
\text { on-line modules } \\
\text { exist makes me feel } \\
\text { that the Law School } \\
\text { has a useful } \\
\text { support system to } \\
\text { help me develop } \\
\text { the skills I require }\end{array}$ & $\begin{array}{l}\text { Knowing I can } \\
\text { come back and re- } \\
\text { complete on-line } \\
\text { modules at any } \\
\text { time reduces my } \\
\text { stress }\end{array}$ & $\begin{array}{l}\text { I find developing } \\
\text { skills relevant to } \\
\text { the study of law to } \\
\text { be a stressful } \\
\text { aspect of my } \\
\text { learning }\end{array}$ \\
\hline First year $(n=64)$ & 4.63 & 4.81 & 4.64 & 4.25 \\
\hline $\begin{array}{l}\text { Second and third } \\
\text { year ( } n=83)\end{array}$ & 4.17 & 4.12 & 4.23 & 3.99 \\
\hline $\begin{array}{l}\text { Fourth and } \\
\text { subsequent years } \\
\text { (n=79) }\end{array}$ & 3.91 & 3.91 & 3.73 & 3.35 \\
\hline $\begin{array}{l}\text { Significance (one-way } \\
\text { independent ANOVA) }\end{array}$ & $\begin{array}{l}\mathrm{F}(2,225)=5.75, \\
p<.05\end{array}$ & $\begin{array}{l}\mathrm{F}(2,225)=9.38, \\
p<.05\end{array}$ & $\begin{array}{l}\mathrm{F}(2,225)=6.48, \\
p<.05\end{array}$ & $\begin{array}{l}\mathrm{F}(2,225)=7.58, \\
p<.05\end{array}$ \\
\hline
\end{tabular}

Figure 15. Degree progression differences in student mean responses

More advanced students still found the modules advantageous, but did not feel as strongly as earlier-year students. Interestingly, later-year students also reported less anxiety over skills acquisition, which may account for the lower perceived usefulness of the online modules amongst that cohort. Age accordingly did not statistically impact on perceptions of the online learning modules, although progression through the degree did appear to reduce student perceptions of the benefits arising from the modules.

\section{International students}

Our results revealed some interesting differences in the perceptions of the online learning modules by international students compared with domestic students. International student responses were not statistically significantly different from domestic students across the measures of the benefits offered by the online learning modules, nor did their experience differ in finding skills development 'a stressful aspect of learning' which was ameliorated by the modules which 'provided useful support' in skills development. International students were, however, significantly more positive in their responses to three questions about the modules, as reported in Figure 16 (at the top of the following page).

As Figure 16 shows, international students reported a significantly greater reduction in stress due to being able to revise the modules on demand, confirming Ireland's (2008, p. 154) finding that particular benefits arise from online learning for international students in terms of revision. Further, international students overall, on the basis of the existence of these online learning modules, felt much more positively about the support systems the school provided. This is particularly interesting given a prior study which suggests international students have comparable levels of psychological distress to domestic students in Australian law schools (Larcombe et al. 2013, p. 423).

International students, therefore, derived particularly strong support from the online learning modules compared with domestic students, with the ability to revise on demand being a key area where international students perceived a stronger advantage than domestic students. 


\begin{tabular}{|l|l|l|l|}
\hline $\begin{array}{l}\text { Mean Response for } \\
\text { International/Domestic } \\
\text { Students: }\end{array}$ & $\begin{array}{l}\text { The fact that these on- } \\
\text { line modules exist } \\
\text { makes me feel that the } \\
\text { Law School has a useful } \\
\text { support system to help } \\
\text { me develop the skills I } \\
\text { require }\end{array}$ & $\begin{array}{l}\text { Knowing I can come } \\
\text { back and re-complete } \\
\text { on-line modules at any } \\
\text { time reduces my stress }\end{array}$ & $\begin{array}{l}\text { I feel that there needs } \\
\text { to be more on-line } \\
\text { teaching methods used } \\
\text { by the law school (i.e. } \\
\text { on-line modules, and } \\
\text { on-line exercises) }\end{array}$ \\
\hline Domestic $(n=204)$ & 4.18 & 4.10 & 3.65 \\
\hline International $(n=22)$ & 4.82 & 4.82 & 4.36 \\
\hline $\begin{array}{l}\text { Significance } \\
\text { (independent samples } \\
t \text {-tests) }\end{array}$ & $t(224)=2.16, p<.05$ & $t(224)=2.08, p<.05$ & $t(224)=2.19, p<.05$ \\
\hline
\end{tabular}

Figure 16. Differences in response from international and domestic students.

Overall, our cohort analyses indicate that the modules were differently experienced for students depending on their progression through the degree, and by international students compared with domestic students. We found no evidence of a difference arising from age or gender.

\section{Conclusion}

Our empirical analysis of student survey and focus group data generally supports a conclusion that the project was successful in achieving its key aims of improving student skills learning, and in so doing minimising one source of the anxiety and stress that impacts so severely on law students.

Partly as a result of the design of our modules, student responses indicated the most positive experience was for less experienced students, with a positive but weaker response from students who were further advanced in their degrees. International students also found the modules to be even more beneficial (particularly in terms of the ability to revise the modules on demand) compared with domestic students. Our results did not support the existence of gender or age differences in the experience offered by the modules.

Overall, students found the modules useful. They valued the flexibility to control their learning process offered to them by the modules, and the ability to review the modules subsequently. However, the most highly valued attribute for students was the perceived ability of the modules to assist in completing assessment tasks. That students found the modules helpful in this way is a demonstration of their relevance however, it also demonstrates an assessment-driven approach to learning that may be problematic in relation to student well-being. Interestingly, students placed little value on the simple fact the modules introduced a variety of learning modes, being discerning enough to focus on their view of the effectiveness of the modules as opposed to their novelty.

Our data also confirm our suspicion that skills acquisition is a source of stress for Australian law students. Moreover, our results demonstrate that online skills development can be effective in reducing the level of stress reported by students and in generating a sense of well-being arising from the feeling that appropriate supports are in place to assist student learning. These results are consistent with the expectation based on this project's use of self-efficacy theory. 
Our research, therefore, demonstrates the potential for online skills development to complement and supplement existing face-to-face teaching of legal skills in law schools, leading to enhanced skills learning and the potential to reduce the level of stress and anxiety experienced by law students. It is anticipated that these benefits would be generalisable to law students in jurisdictions other than Australia who are known to suffer similar issues with well-being and anxiety. Future research could extend this study by employing an instrument to expressly measure student psychological well-being before and after an intervention using online professional skills development - such psychometric analysis was beyond the scope of this project.

\section{Notes}

1. University of Adelaide Human Research Ethics Committee Approval number HP2012-069.

2. Year levels indicated are based on a full-time graduate student pathway. Undergraduate students, those undertaking an LLB combined with another degree, and part-time students, would progress more slowly.

3. Dr Edward Palmer, Senior Lecturer, School of Education, University of Adelaide and Professor Vicki Waye, Professor of Law and Dean of Teaching and Learning, Business School, The University of South Australia.

4. University of Adelaide Human Research Ethics Committee Approval number H-2014-014.

\section{References}

Australian Law Reform Commission. (1999) Managing Justice: A Review of the Federal Civil Justice System, ALRC, Sydney.

Bandura, A. (1977) 'Self-efficacy theory: toward a unifying theory of behavioural change', Psychological Review, vol. 84, pp. 191-215.

Bandura, A. (1997) Self-Efficacy: The Exercise of Control, Freeman, New York.

Benjamin, G. A., et al., (1986) 'The role of legal education in producing psychological distress among law students and lawyers', American Bar Foundation Research Journal, vol. 2, pp. $225-252$.

Buckingham, D. (2007) 'Digital media literacies: rethinking media education in the age of the Internet', Research in Comparative and International Education, vol. 21, no. 1, pp. 43-55.

Burgstahler, S., Corrigan, B. \& McCarter, J. (2004) 'Making distance learning courses accessible to students and instructors with disabilities: a case study', Internet and Higher Education, vol. 7, pp. 233-246.

Butler, D. (2010) 'Entry into Valhalla: contextualising the learning of legal ethics through the use of second life Machima', Legal Education Review, vol. 20, pp. 87-110.

Cagiltay, K. (2006) 'Scaffolding strategies in electronic performance support systems: types and challenges', Innovations in Education and Teaching International, vol. 43, no. 1, 93-103.

Coldwell, J., et al., (2007) 'Gender and equity in e-learning', Australasian Journal of Information Systems, vol. 15, no. 1, pp. 9-24.

Comber, C., et al., (1997) 'The effects of age, gender and computer experience upon computer attitudes', Educational Research, vol. 39, no. 2, pp. 123-133.

Culp, D. (1994) 'Law school: A mortuary for poets and moral reason', Campbell Law Review, vol. 16, pp. 61-101.

Dammeyer, M. \& Nunez, N. (1999) 'Anxiety and depression among law students: current knowledge and future directions', Law and Human Behavior, vol. 23, no. 1, pp. 55-73.

Deci, E. \& Ryan, R. (1985) Intrinsic Motivation and Self-determination in Human Behavior, Plenum Press, New York.

Durndell, A. \& Hagg, Z. (2002) 'Computer self efficacy, computer anxiety, attitudes towards the Internet and reported experience with the Internet, by gender, in an East European sample', Computers in Human Behavior, vol. 18, pp. 521-535.

Edwards, H. T. (1992) 'The growing disjunction between legal education and the legal profession', Michigan Law Review, vol. 91, pp. 34-70. 


\section{A. Hewitt and M. Stubbs}

Fichten, C., et al., (2000) 'Access to educational and instructional computer technologies for post-secondary students with disabilities: lessons from three empirical studies', Journal of Educational Media, vol. 25, no. 3, pp. 179-201.

Fichten, C., et al., (2001) 'Technology integration for students with disabilities: empirically based recommendations for faculty', Educational Research and Evaluation, vol. 7, no. 2, pp. $185-221$.

Fichten, C., et al., (2009) 'Disabilities and e-learning problems and solutions: an exploratory study', Journal of Educational Technology \& Society, vol. 12, no. 4, pp. 241-256.

Glance, D., Forsey, M. \& Riley, M. (2003) 'The pedagogical foundations of massive open online courses', First Monday, vol. 18, no. 5, [online] Available at: http://firstmonday.org/ ojs/index.php/fm/article/view/4350/3673

Grant, L. \& Spencer, R. (2003) 'The personalized system of instruction: review and applications to distance education', International Review of Research in Open and Distance Learning, vol. 4 , no. 2 , pp. $1-17$.

Guskey, T. (1997) Implementing Mastery Learning, 2nd edn, Wadsworth Publishing Company, Belmont, CA.

Handsley, E., Davis, G. \& Israel, M. (2005) 'Law school lemonade: or can you turn external pressures into educational advantages?', Griffith Law Review, vol. 14, pp. 108-133.

Hartman, J., Moskal, P. \& Dziuban, C. (2005) 'Preparing the academy of today for the learner of tomorrow', in Educating the Net Generation, eds D. G. Oblinger \& J. L. Oblinger, Educause, Washington, DC, [online] Available at: http://www.educause.edu/research-andpublications/books/educating-net-generation

Helmers, K., et al., (1997) 'Stress and depressed mood in medical students, law students, and graduate students at McGill University', Academic Medicine, vol. 72, no. 8, pp. 708-714.

Hewitt, A. (2015) 'Can you learn to lawyer online? A blended learning environment case study', The Law Teacher: The International Journal of Legal Education, vol. 1, pp. 92-121.

Hewitt, A. \& Stubbs, M. (2013) 'Using e-learning tools to open the gate to professional skills acquisition', Paper presented to Australian Law Teachers Association Conference, Australian National University, Canberra, 30 September 2013.

Hewitt, A. \& Toole, K. (2013) 'The practical knowledge conundrum: what practical knowledge should be included in a law school curriculum and how can it be taught?', New Zealand Universities Law Review, vol. 25, pp. 980-1022.

Hill, J. \& Hannafin, M. (2001) 'Teaching and learning in digital environments: the resurgence of resource-based learning', Educational Technology Research and Development, vol. 49, no. 3, pp. $37-52$.

Howe, N. \& Strausse, W. (2000) Millennials Rising: The Next Great Generation, Vintage, New York.

Huggins, A. (2012) 'Autonomy supportive curriculum design: A salient factor is promoting law students' wellbeing', University of New South Wales Law Journal, vol. 35, pp. 683-716.

Ireland, J. (2008) 'Blended learning in intellectual property: The best of both worlds', Legal Education Review, vol. 18, pp. 139-162.

Johnstone, R. \& Vignaendra, S. (2003) Learning Outcomes and Curriculum Development in Law, Australian Universities Teaching Committee, Canberra.

Karpick, J. \& Roedinger, H. (2008) 'The critical importance of retrieval for learning', Science, vol. 319 , pp. 966-968.

Katz, R. (2006) The ECAR Study of Undergraduate Students and Information Technology, Educause Centre for Applied Research, Boulder, CO.

Kelk, N., et al., (2009) Courting the Blues: Attitudes towards depression in Australian Law Students and Lawyers, Brain \& Mind Research Institute, University of Sydney, Camperdown.

Keller, F. (1968) 'Goodbye teacher', Journal of Applied Behavior Analysis, vol. 1, pp. 79-89.

Kendrick, D. (2010) 'Cost effectiveness in course redesign: the transformation towards e-learning, in Web-Based Education: Concepts, Methodologies, Tools and Applications, ed Information Resources Management Association, Information Science Reference, Hershey, PA, vol. 1, pp. 1392-1399. 
Kift, S., Israel, M. \& Field, R. (2010) Bachelor of Laws Learning and Teaching Academic Standards Statement, [online] Available at: http://www.cald.asn.au/assets/lists/ALSSCResources/ KiftetalLTASStandardsStatement2010.pdf

Kirkup, G. (2002) ICT as a Tool for Enhancing Women's Education Opportunities; and New Educational and Professional Opportunities for Women in New Technologies, United Nations Division for the Advancement of Women, [online] Available at: http://oro.open. ac.uk/id/eprint/681

Ky, H. Y. \& Lohr, L. L. (2003) 'A case study of Chinese students' attitudes toward their first online learning experience', Educational Technology Research and Development, vol. 51, no. 3, pp. 94-102.

Larcombe, W., et al., (2013) 'Does an improved experience of law school protect students against depression, anxiety and stress? An empirical study of wellbeing and the law school experience of LLB and JD students', Sydney Law Review, vol. 35, pp. 407-432.

Leahy, C., et al., (2010) 'Distress levels and self-reported treatment rates for medicine, law, psychology and mechanical engineering tertiary students: cross-sectional study' Australian and New Zealand Journal of Psychiatry, vol. 44, pp. 608-615.

Lloyd Williams, S. (1995) 'Self-efficacy and anxiety and phobic disorders', in Self-Efficacy, Adaption and Adjustment: Theory, Research and Application, ed. J. Maddux, Plenum Press, New York, pp. 69-107.

Lord Chancellor's Advisory Committee on Legal Education and Conduct. (1996) First Report on Legal Education and Training, ACLEC, London.

Lorenzo, G., Oblinger, D. \& Dziuban, C. (2007) 'How choice, co-creation, and culture are changing what it means to be Net Savvy', Educause Quarterly, vol. 1, pp. 6-12.

Maddux, J. (ed) (1995) Self-Efficacy, Adaption and Adjustment: Theory, Research and Application, Plenum Press, New York.

Maddux, J. \& Meier, L. (1995) 'Self-efficacy and depression', in Self-Efficacy, Adaption and Adjustment: Theory, Research and Application, ed. J. Maddux, Plenum Press, New York, pp. 143-169.

Martin, F. (2003) 'Teaching legal problem solving: A problem-based learning approach combined with a computerised generic problem', Legal Education Review, vol. 14, no. 1, pp. 77-92.

Mascher, S. \& Skead, N. (2011) 'On the record: the trials and tribulations of lecture recording in law', University of Western Australia Law Review, vol. 35, pp. 407-432.

McFarland, P. \& Fuller, A. (2001) 'Equity issues in e-education', Journal of Law and Information Science, vol. 12, pp. 87-96.

McKinney, D., Dyck, J. \& Luber, E. (2009) 'iTunes University and the classroom: can podcasts replace professors?', Computers \& Education, vol. 52, pp. 617-623.

McKinney, R. A. (2002) 'Depression and anxiety in law students: are we part of the problem and can we be part of the solution?' Legal Writing: The Journal of the Legal Writing Institute, vol. 8, pp. 229-255.

McNamara, L. (2000) 'Lecturing (and not lecturing) using the web: Part 1', Legal Education Review, vol. 11, pp. 149-174.

Muilenburg, L. Y. \& Berge, Z. L. (2005) 'Student barriers to online learning: a factor analytic study', Distance Education, vol. 26, no. 1, pp. 29-48.

National Alternative Dispute Resolution Advisory Council. (2012) Teaching Alternative Dispute Resolution in Australian Law Schools, NADRAC, Canberra.

Nordmo, I. \& Samara, A. (2009) 'The study experiences of the high achievers in a competitive academic environment: a cost of success?', Issues in Educational Research, vol. 19, no. 3, pp. $255-270$.

Okebukola, P. \& Woda, A. (1993) 'The gender factor in computer anxiety and interest among some Australian high school students', Educational Research, vol. 35, no. 2, pp. 181-189.

Oliver, B. \& Goerke, V. (2007) 'Australian undergraduates' use and ownership of emerging technologies: implications and opportunities for creating engaging learning experiences for the Net Generation', Australasian Journal of Educational Technology, vol. 23, no. 2, pp. 171-186.

Peterson, T. \& Peterson, E. W. (2009) 'Stemming the tide of law student depression: what law schools need to learn from the science of positive psychology', Yale Journal of Health, Policy, Law \& Ethics, vol. 9, no. 2, pp. 357-434.

Schrum, L. (2002) 'Dimensions and strategies for online success: voices from experienced educators', Journal of Asynchronous Learning Networks, vol. 6, no. 1, pp. 57-67. 


\section{A. Hewitt and M. Stubbs}

Seale, J. \& Cooper, M. (2010) 'E-learning and accessibility: an exploration of the potential role of generic pedagogical tools', Computers \& Education, vol. 54, no. 4, pp. 1107-1116.

Selim, H. (2007) 'Critical success factors for e-learning acceptance: confirmatory factor models', Computers \& Education, vol. 49, pp. 396-413.

Shattuck, K. (2005) Glimpse of the Global Coral Gardens: Insights of International Adult Learners on the Interactions of Cultures in Online Distance Education, Unpublished Doctoral thesis, Pennsylvania State University.

Stefancic, J. \& Delgado, R. (2005) How lawyers lose their way: a profession fails its creative minds, Duke University Press, Durham, NC.

Stubbs, M. \& Hewitt, A. (2013) 'Can we teach professional skills in the cyber world? Creating e-learning legal skills development tools', Paper presented to 'Bricks to Bytes?': Higher Education Research Group of Adelaide Conference, Adelaide, 27 September 2013.

Sullivan, W. M., et al., (2007) Educating Lawyers: Preparation for the Profession of Law, JosseyBass, San Francisco, CA.

Tani, M. \& Vines, P. (2009) 'Law students' attitudes to education: pointers to depression in the legal academy and the profession?', Legal Education Review, vol. 19, pp. 3-40.

Tapscott, C. (1998) Growing up Digital: The Rise of the Net Generation, McGraw-Hill, New York.

U.S. Department of Education, Office of Planning, Evaluation, and Policy Development. (2010) Evaluation of Evidence-Based Practices in Online Learning: A Meta-Analysis and Review of Online Learning Studies, [online] Available at: http://www.ed.gov/about/offices/ list/opepd/ppss/reports.html

Walker-Fernandez, S. E. (1999) Toward Understanding the Study Experience of Culturally Sensitive Graduate Students in American Distance Education Programs, Unpublished Doctoral dissertation, Florida International University, [online] Available at: http:// digitalcommons.fiu.edu/dissertations/AAI9952373/

Watson, P. \& Field, R. (2011) 'Promoting student well-being and resilience at law school' in Excellence and Innovation in Legal Education, ed S. Kift et al., LexisNexis, Chatswood, NSW, pp. 389-420.

Whitely, B. (1997) 'Gender differences in computer related attitudes and behaviour: a meta analysis', Computers in Human Behavior, vol. 13, no. 1, pp. 1-22.

Woods, D., et al., (2000) 'The future of engineering education III: Developing critical skills', Chemical Engineering Education, vol. 34, no. 2, pp. 108-117.

Yule, J., NcNamara, J. \& Thomas, M. (2010) 'Mooting and technology: to what extent does using technology improve the mooting experience for students?', Legal Education Review, vol. 20, pp. 137-156.

Zhang, Z. \& Kenny, R. F. (2010) 'Learning in an online distance education course: experiences of three international students', The International Review of Research in Open and Distributed Learning, vol. 11, no. 1, [online] Available at: http://www.irrodl.org/index. php/irrodl/article/view/775/1481 